Research Article

\title{
Comparative study of Eugenia jambolana seed and pulp for antidiabetic action on alloxan induced diabetic rats
}

\author{
Farhana Rahman ${ }^{1}$, Seema Baishnab ${ }^{2 *}$
}

\author{
${ }^{1}$ Deptment of Pharmacology, \\ Sree Balaji medical college \\ hospital, Chennai, India \\ ${ }^{2}$ Department of Pharmacology, \\ MAMC, Agroha, Hisar, \\ Haryana, India
}

Received: 13 May 2016 Accepted: 09 June 2016

\section{*Correspondence to: Dr. Seema Baishnab, Email: seemabaishnab @yahoo.co.in}

Copyright: (C) the author(s), publisher and licensee Medip Academy. This is an openaccess article distributed under the terms of the Creative Commons Attribution NonCommercial License, which permits unrestricted noncommercial use, distribution, and reproduction in any medium, provided the original work is properly cited.

\begin{abstract}
Background: Eugenia jambolana Lam., commonly known as black plum or "jamun" is an important medicinal plant in various traditional systems of medicine. It is effective in the treatment of diabetes mellitus, inflammation, ulcers and diarrhoea and preclinical studies have also shown it to possess chemopreventive, radioprotective and antineoplastic properties. The aim of the present study is to compare the action of extract of Eugenia jambolana (Jamun) seed with pulp on blood glucose level in alloxan-induced diabetic albino rats. Methods: The extracts $(100 \mathrm{mg} / \mathrm{kg} / \mathrm{d})$ were administered orally for four weeks to alloxan-induced diabetic rats. Blood glucose was estimated every week for four consecutive weeks.

Results: The test drugs that is Eugenia jambolana seed showed more significant $(\mathrm{p}<0.05)$ than pulp in reduction of blood glucose induced by alloxan. Conclusions: Thus, Eugenia jambolana seeds show more antidiabetic effect than Eugenia jambolana pulp. However, further studies to isolate the active principle of Eugenia jambolana responsible for hypoglycemia, together with studies on serum insulin assay to confirm its insulin releasing action have to be undertaken.
\end{abstract}

Keywords: Antidiabetic, Eugenia jambolana, Alloxan, Ethanol extract

\section{INTRODUCTION}

Syzygium cumini (Family Myrtaceae) is also known as Syzygium jambolanum and Eugenia cumini. Other common names are Jambul, Black Plum, Java Plum, Indian Blackberry, Jamblang, Jamun etc. Today these trees are found growing throughout the Asian subcontinent, Eastern Africa, South America, Madagascar and have also naturalized to Florida and Hawaii in the United States of America. ${ }^{1}$ The tree fruits once in a year and the berries are sweetish sour to taste. The ripe fruits are used for health drinks, making preserves, squashes, jellies and wine. ${ }^{1}$ In association to its dietary use, all parts of the tree and, importantly the seeds are used to treat a range of ailments, the most important being diabetes mellitus. ${ }^{2}$
Diabetes mellitus (DM) refers to a group of common metabolic disorders that share the phenotype of hyperglycemia. ${ }^{3}$ A changing lifestyle in developing countries like India has enormously increased the statistical figures of diabetes mellitus. A survey depicts that $4 \%$ of adults in India suffered from DM in year 20000 and it is expected to increase by $6 \%$ by the year $2025^{4}$

In Unani Medicine various parts of Jambolan acts as liver tonic, enrich blood, strengthen teeth and gums and form good lotion for removing ringworm infection of the head. E. jambolana leaf extract showed hypoglycemic action in diabetic rats. ${ }^{5} \mathrm{~A}$ fruit extract showed antimicrobial and cytotoxic activities and may potentially be used on topical antimicrobial products. In comparison to other 
non-traditional fruits jambolao showed considerable high antioxidant activity, which can constituent such as anthocyanins, tannins and flavonols. ${ }^{6}$ Seeds contains phytochemicals like Jambosine, gallic acid, ellagic acid, corilagin, 3,6-hexahydroxy diphenoylglucose, 1 -galloylglucose, 3-galloylglucose, quercetin, $\beta$-sitoterol, 4,6-hexahydroxydiphenoylglucose. ${ }^{7,8}$ Keeping this in view, the present study was aimed for comparing the effect of Eugenia jambolana seed with Eugenia jambolana pulp on blood glucose level in alloxan-induced diabetic albino rats.

\section{METHODS}

\section{Plant material and extraction}

Eugenia jambolana fruit was obtained from the local market in the months of June to August and identified by the Department of Botany, Assam University, Dibrugarh, Assam.

\section{Drugs}

Alloxan (Sigma Bangalore), glibenclamide, appropiate vehicle controls were employed in all experiments. The ethanolic extracts were suspended in $3 \%$ gum acacia.

\section{Extraction}

The required amount of seed and fruit pulp of E. jambolana were collected and dried in room temperature. About $500 \mathrm{gm}$ of both the seed and pulp were ground separately into powdered form and packed separately into the percolator along with $90 \%$ ethyl alcohol for $48 \mathrm{hrs}$. Materials were collected from the percolater and alcohol was allowed to evaporate. ${ }^{9}$

\section{Phytochemical constituents of E. jambolana}

Alkaloids, amino acids, flavonoids, glycosides, phytostgerol, saponins, steroids, tannins, triterpenoids. ${ }^{10}$

\section{Animals}

Healthy adult Wistar albino rats (Rattus norvegicus) weighing 200-250 grams each were used for the individual study. All the animals were taken care of under ethical consideration as per the guidelines of the CPCSEA with due approval from the Institutional Animal Ethical Committee (Registration no: 634/02/a/CPCSEA; dated 19/5/2002).

The animals were selected randomly and divided in five groups consisting of 6 animals in each group. All the animals were treated for 4 weeks.

Group 1: Normal control (3\% gum acacia suspension) $5 \mathrm{ml} / \mathrm{kg}$ b.w/day p.o.
Group 2: Diabetic control (3\% gum acacia suspension) $5 \mathrm{ml} / \mathrm{kg}$ b.w/day p.o.

Group 3: Seed of E. jambolana $100 \mathrm{mg} / \mathrm{kg}$ b.w./day p.o.

Group 4: Pulp of E. jambolana $100 \mathrm{mg} / \mathrm{kg}$ b.w/day p.o.

Group 5: Glibenclamide $25 \mathrm{mg} / \mathrm{kg}$ b.w/day p.o

After every 1 week fasting blood samples were taken from the orbital sinus of the treated animals and blood glucose level were measured by glucose oxidase method. ${ }^{11}$

\section{Induction of diabetes}

A single dose (150 mg/kg b.w. IP) of alloxan monohydrate dissolved in normal saline was used for induction of type II diabetes in rats after overnight fasting. After $1 \mathrm{hr}$ of alloxan administration, the animals were fed standard pellets and water ad libitum. The animals were. The animals were stabilized for 72 hours and animals showing blood glucose level (estimated by glucose oxidase method) more than $200 \mathrm{mg} / \mathrm{dl}$ were selected for the study.

\section{Statistical analysis}

The data was statistically analysed for individual effect by using One-way ANOVA followed by Dunnett's multiple comparison test. ${ }^{12,13}$ Values of $\mathrm{p}<0.01$ were considered significant. For comparative study Mann Whitney U Test (non-parametric test) was done. ${ }^{14}$ Values of $p<0.05$ were considered significant.

\section{RESULTS}

\section{Effect on blood glucose level}

Analysis of data done after four weeks shows that E. jambolana (100 mg/kg body wt) seed extract showed statistically significant decrease $(\mathrm{p}<0.05)$ in the blood glucose level when comparison was done with Eugenia jambolana pulp extract (100 $\mathrm{mg} / \mathrm{kg}$ body wt) group done by Mann Whitney U Test (non-parametric test).

Table 1: Blood glucose level observed in test group.

\begin{tabular}{|llll|}
\hline Group & Mean & SD & SEM \\
\hline Seed & 100 & 3.40 & 1.39 \\
\hline Pulp & 129.50 & 2.43 & 0.99 \\
\hline
\end{tabular}

Both the extract exhibited a statistically significant decrease $(p<0.01)$ in the blood glucose level when comparison was done with diabetic control group .Values are expressed as Mean \pm SEM; $n=6$ rats in each group. One-way ANOVA followed by Dunnett's multiple comparison tests was done. $\mathrm{p}<0.01$ when compared to 
normal control group. $\mathrm{p}<0.01$ when compared to diabetic control group.

\section{DISCUSSION}

From the study, it was seen that E. jambolana both seed and pulp significantly $(\mathrm{p}<0.01)$ lowered the blood glucose level in diabetic rats. In comparative study E. Jambolana seeds showed significantly $(\mathrm{p}<0.01)$ lowered blood glucose level than Eugenia jambolana pulp in diabetic rats. Alloxan, a $\beta$-cytotoxic agent, rapidly and selectively accumulates in pancreatic $\beta$-cells and causes $\beta$-cell death and apoptosis by generation of reactive oxygen species (ROS), superoxide radicals and hydrogen peroxide. ${ }^{15}$ $\beta$ cell death causes hyperglycemia due to insulin deficiency which further aggravates the oxidative stress induced by alloxan. ${ }^{16}$ Flavonoids are also known to regenerate the damage beta cells in the alloxan diabetic rats. ${ }^{17}$ The flavonoids may be responsible for hypoglycaemic action of E. jambolana. The antioxidant activity might be due to the presence of phenolic compounds such as flavonoids. ${ }^{18}$ Furthermore, previous studies have reported the protective action of flavonoids against oxidative stress induced cellular damage and also the ability of flavonoids to regenerate $\beta$-cells. ${ }^{19,20}$

\section{CONCLUSION}

Thus, Eugenia jambolana seeds show more antidiabetic effect than Eugenia jambolana pulp. However, further studies to isolate the active principle of Eugenia jambolana responsible for hypoglycemia, together with studies on serum insulin assay to confirm its insulin releasing action have to be undertaken.

\section{Funding: No funding sources}

Conflict of interest: None declared

Ethical approval: The study was approved by the Institutional Ethics Committee

\section{REFERENCES}

1. Warrier P, Nambiar V, Ramankutty C. Indian Medical Plants. Volume 5. Hyderabad:Orient Longman Ltd;1996:225-228.

2. Ayyanar M, Subash-Babu P, Ignacimuthu S. Syzygium cumini (L.) Skeels., a novel therapeutic agent for diabetes: folk medicinal and pharmacological evidences. Complement Ther Med. 2013;21(3):232-43.

3. Power AC. Diabetes Mellitus. Harrison`s principles of internal medicine. Vol-2. 17th Edn. New York, NY: Mc Graw Hill Companies; 2008:2275.

4. King H, Aubert RE, Herman WH. Global burden of diabetics 1995-2025: prevalence numerical estimates and projections. Diabetes care. 1998;21:1413-4.

5. Bhatia IS, Bajaj KL. Chemical constituents of the seeds and bark of Syzygium cumini. Planta Medica. 1975;28:346-52.
6. Gordon A, Jungfer E. Phenolic constituents and antioxidant capacity of four underutilized fruits from the Amazon region. J Agricultural Food Chem. 2011;59:7688-99.

7. Sagrawat H, Mann A, Kharya M. Pharmacological potential of Eugenia jambolana: a review. Pharmacogenesis Magazice. 2006;2:96-104.

8. Rastogi R, Mehrotra B. Compendium of Indian medicinal plants. Central Drug Research Institute, Lucknow. 1990;1:388-9.

9. Pharmaceutical formulas. 11th ed. London: Chemist and Druggist Publishers; 1950;1:183-184.

10. Kumar A, Ilavarasan R, Jayachandran T, Decaraman M, Aravindhan P, Padmanabhan N, Krishan MRV. Phytochemical Investigation on a Tropical Plant, Syzygium cumini from Kattuppalayam, Erode District, Tamil Nadu, South India. Pakistan J Nutr. 2009;8(1):83-5.

11. Gowenlock AH, Janet R, Mc Murray D, Mc L. Glucose and other sugars and ketones. Valley's practical clinical biochemistry. $6^{\text {th }}$ ed. New Delhi; CBS publisher and distributors; 2002:321-323.

12. Chiplonkar SA, Rao KV. Analysis of variance. In: Rao KV, editor. Biostatistics: a manual of statistical methods for use in health, nutrition and anthropology. 1st Edn. New Delhi: Jaypee Brothers, Medical Publishers (P) Ltd.; 1996:237-272.

13. Rao KV, Balakrishna N. Multiple comparison test procedures: relative utility. In: Rao KV, editor. Biostatistics: a manual of statistical methods for use in health, nutrition and anthropology. 1st Edn. New Delhi: Jaypee Brothers, Medical Publishers (P) Ltd; 1996:273-284.

14. Kulkarni SK. Handbook of experimental pharmacology. \#rd revised Edn. Delhi: Vallabh prakashan publishers; 2004:183-185.

15. Szkudelski T. The mechanism of alloxan and streptozotocin action in B cells of the rat pancreas. Physiol Res. 2001;50:536-46.

16. Kaneto H, Fujii J, Myint T, Miyazawa N, Islam KN, Kawasaki Y, et al. Reducing sugars trigger oxidative modification and apoptosis in pancreatic cells by provoking oxidative stress through the glycation reaction. Biochem J. 1996;320:855-63.

17. Chakkvarthy BK, Gupta S, Gambir SS, Gode KD. Pancreatic beta cell regeneration. A novel antidiabetic mechanism of Pterocarpus marsupium Roxb. Indian J Pharma. 1980;12:123-7.

18. Pietta P, Simonetti P Mauri P. Antioxidant activity of selected medicinal plants. J Agric Food Chem. 1998;46:4487-90.

19. Evans WC. Trease and Evans Pharmacognosy. 15th ed. Philadelphia: Saunders, an imprint of Elsevier Limited; 2002:214-252.

20. Kaneto H, Kajimoto Y, Miyagawa J, Matsuoka T, Fujitani Y, Umayahara Y, et al. Beneficial effects of antioxidants in diabetes: possible protection of cells against glucose toxicity. Diabetes. 1999;48:2398406.

Cite this article as: Rahman F, Baishnab S.

Comparative study of Eugenia jambolana seed and pulp for antidiabetic action on alloxan induced diabetic rats. Int J Basic Clin Pharmacol 2016;5:130810 . 